\title{
Noninterest Income and Performance of Commercial Banking in China
}

\author{
Limei Sun, ${ }^{1}$ Siqin Wu, ${ }^{1}$ Zili Zhu, ${ }^{2}$ and Alec Stephenson ${ }^{2}$ \\ ${ }^{1}$ School of Economics and Management, Harbin Engineering University, Heilongjiang, China \\ ${ }^{2}$ Data 61, CSIRO, Melbourne, VIC, Australia \\ Correspondence should be addressed to Limei Sun; slm0451@163.com
}

Received 27 September 2016; Revised 3 November 2016; Accepted 21 November 2016; Published 15 February 2017

Academic Editor: Xiaofeng Xu

Copyright (c) 2017 Limei Sun et al. This is an open access article distributed under the Creative Commons Attribution License, which permits unrestricted use, distribution, and reproduction in any medium, provided the original work is properly cited.

\begin{abstract}
Noninterest income is what most Chinese banks are striving for in recent years because of the vigorous competition among commercial banks due to the increasingly open market and tough regulation from the central bank of China. But the problem is the real effect of noninterest income on profit and risks. A panel threshold model is used with balanced panel dataset of 16 listed Chinese commercial banks, for the period of 2007 to 2013, to investigate the relationship between noninterest income and performance. The findings show two main conclusions: (1) the existence of two thresholds shows that there is nonlinear relationship; (2) there is a general negative correlation between the noninterest income ratio and performance of commercial banks. Furthermore, when the noninterest income ratio is higher than the two thresholds, the negative correlation decreases. Implications of the paper are that the ratio should be controlled in a range or noninterest income will not positively affect the performance, and a high level of performance can be gained only by raising the ratio to a certain level.
\end{abstract}

\section{Introduction}

With the significant development of financial liberalization and globalization, banks choosing to expand their noninterest income activities are confronted with increasingly severe interbank competition so as to grow, realize efficiency, and reduce idiosyncratic risk [1]. The Chinese banking industry has just started its focus on diversification of business in recent years. The noninterest income business has had continuous development. But whether noninterest income can help enhance bank performance has always been controversial. Some previous literature pays a lot of attention to the relationship between noninterest based activities and the performance of banks in countries outside of China. However, similar attention has not been given much to the Chinese case. This paper investigates the relationship between noninterest income ratio and the performance of Chinese commercial banks' and the influence of noninterest income ratio on its performance. The remainder of the paper is structured as follows. In Section 2 we describe recent academic developments in this field. In Section 3 we review mechanism of the noninterest income which affects the performance. In Section 4 the dataset and the empirical model are described. In Section 5 we present and interpret the empirical results. Finally, policy implication of the paper has been drawn in Section 6.

\section{Literature Review}

Researchers from USA, UK, India, Ghana, and so on have explored relationships between noninterest income and business performance [2-11] (Abeyratna Gunasekarage et al., 2014). There are three different schools of thought on optimal bank scope. One set of arguments hold that restricting banking scope to the traditional activities reduces likelihood of failure related to risk businesses, while the second set argue that noninterest income enhances bank profitability and reduces risk; the third set holds that impact of noninterest income on bank performance is uncertain.

Some researchers deem that noninterest income business can improve the total income, since banks can expand the source of income by diversifying income. Eisemann [12] stated that the noninterest income business was composed 
of commissions and fees, which could enhance the profit of banks by expanding source of earning; Busch and Kick [13] discovered that noninterest income has positive correlation with ROE and ROA; Aggeler and Feldman [14] discovered that the profit of the bank depends mostly on noninterest income but not interest income as people generally expect. The Chinese scholars Sheng and Wang [15] think that the rise of the noninterest's proportion in total income can efficiently improve the performance of commercial banks. Goddard et al. [4] study the impact of revenue diversification of US credit unions on financial performance for the period 1993-2004. Their research finds that a positive direct exposure effect is outweighed by a negative indirect exposure effect for all but the largest credit unions. Sanya and Wolfe [16] use SystemGMM and 226 listed banks in 11 emerging economies dating from 2000 to 2007 to explore diversification across and within both interest and noninterest income generating activities. Their research indicates that diversification decreases insolvency risk and enhances profitability. Saunders et al. [17] use 10,341 US banks as sample and conclude that a higher ratio of noninterest income to interest income is associated with a higher profitability across the banking sector. Nguyen et al. [10] carried out tests on 32 Vietnamese domestic banks with data period of 2005-2012. Their work concludes that banks with high noninterest income present lower risk than those with mainly interest income. A significant number of studies on US banking sector $[2,18]$ show that noninterest income unfavorably affects bank performance by either reducing return or increasing income volatility. However, the study by Saunders et al. [17] with a larger sample of US banks found noninterest income to be associated with higher profitability across all banks groups. Senyo et al. [9] found that noninterest revenue is becoming increasingly relevant and contributes to bank profit stability. Against the view that diversification may impact negatively on performance of banks, Abeyratna Gunasekarage et al. (2014) suggest that diversification of Australia's banks has improved their risk-return. Aslam et al. [19] show that noninterest income and business growth are positively related. Saunders et al. [20] find no convincing evidence that noninterest generating activities harm bank profitability and/or increase bank failure, insolvency, or systematic risks during both crisis and noncrisis periods.

Other researchers suggest that the influence of noninterest income on enhancing the profit of commercial banks is limited or even negatively correlated with performance. Smith et al. [21] argue that the increase of noninterest income cannot totally cover the income reduction. Jing Wang (2009) and Yu Liu and Jia Li (2012) suggest that noninterest income cannot improve the income rate. Research on the US banking system shows that as American banks convert from single business to mixed business, the variability also becomes more severe, which offsets profit coming from the income's diversification and therefore the shift towards noninterest income has not improved the risk-adjusted returns [11] (Hirtle and Stiroh, 2007). Furthermore some researches point out that the noninterest income and the banks' performance are actually negatively correlated and the volatility feature of noninterest income may even do harm to commercial banks' profitability [22, 23] (Jing Wang and Haowen Zhou, 2008; Chao Xue and Zheng li, 2014).
Other researchers show unclear or uncertain impacts from noninterest income. According to Stiroh and Rumble [18], there is no significant correlation between the noninterest income and the average rate of return. The European Central Bank's empirical test result shows that the relationship between performance and the noninterest income as a proportion of total income is uncertain. Yingchun Lou (2008) gives a similar conclusion.

There is a wide range of different conclusions from previous research about how noninterest income influences performance. As to the Chinese case, most researchers focus on only linear modelling approaches. This paper extends these approaches to consider nonlinear models using threshold values. We consider the following aspects: (1) we show the nonlinearity between noninterest income and performance of commercial banks and verify the existence of the threshold; (2) we consider the nonlinear impact of noninterest income on bank performance in different stages of scale using two thresholds; (3) we use data within 2007-2013 to ensure the consistency of the methods of calculation of some variables; the methodology for computation of these variables remained consistent during this period, and therefore our inferences are more robust.

\section{How Noninterest Income Influences Commercial Banking Performance}

3.1. Noninterest Income Business Expands Commercial Banks' Source of Revenue and Cost. The income source of commercial bank includes interest income and noninterest income. Obviously, when the expanding of traditional interest income business faces limitations from relatively stable population and increasingly intense horizontal competition, developing the noninterest income business becomes a main means to maintain and increase the total income level that has been experienced by international banks. Noninterest income can increase the total level of income of commercial banks in several ways: (1) satisfying diversified needs for financial services, investment consultation, and so forth by continuous innovation of new financial products and services in order to gain more fees and commission and strengthen the market competitiveness; (2) improving the investment level of commercial banks in financial markets to gain the investment income from bonds and stocks; (3) enriching income from gains or losses of exchange and profits or losses from changes of fair value and other business.

The operating costs of noninterest income mainly consist of labor costs, marketing expenses, and administrative expenses. When new noninterest financial products are released, the commercial banks have to pay much more to market new services than those invested in traditional interest income activities, and the operating costs will rise greatly. In addition, uncertainty in security market influences the returns of investment. Increasing the investment income requires the commercial bank to have sound investment ability. For some banks, poor ability of investing in the security market resulting from long time focusing on traditional activities may result in a poor performance in noninterest 
income business. The loss in noninterest income activities will lead to loss in total revenue.

\subsection{Noninterest Income Increases Volatility of Bank Earnings.} Volatility brought by noninterest income of commercial banks has been highlighted in a previous literature. Some explain the impact of noninterest income on bank performance with portfolio theory: consistent with portfolio theory, an increased reliance on noninterest income is associated with higher volatility of returns. Similar conclusions have been drawn by Stiroh and Rumble [18], Calmès and Liu [24], Jaffar et al. [7], and Senyo et al. [9] who argue that the banks' greater reliance on noninterest income is associated with higher systemic risk. The results of these studies indicate noninterest income is much more volatile than interest income from a global viewpoint and for each individual bank. Deyoung and Roland [2] proposed three reasons to explain volatility induced by noninterest income on bank earnings. Firstly, switching costs of noninterest income are much lower than that of interest income because most fee-based activities are not relationship based, which contributes to the volatility. Secondly, noninterest income activities may require greater operating leverage than interest income activities because the main input needed to produce more fee-based products is typically fixed or quasi-fixed other than for interest expenses needed to produce more loans. Thirdly, noninterest income activities likely employ greater financial leverage than lending activities, because most noninterest income activities require holding little or no fixed assets and little or no regulatory capital. All these factors lead to volatility from noninterest income, increasing risk for commercial banks.

3.3. Noninterest Income Increases Operating Risk. Firstly, the expansion of noninterest income requires more investment in labor and facility, which leads to increasing operating costs. Thus, the larger operating leverage may induce larger operating risk. To acquire revenue from noninterest income, commercial banks have to invest much in both labor and facilities. These investments lead to high fixed costs. When industry profitability drops with competition among banks and the costs remain stable, the profit level drops sharply. Hence, in this case, high operating leverage will increase the operating risk.

Secondly, noninterest business increases commercial bank's operating risk while innovating new services and new products. During the process of developing noninterest business, it is necessary to create new services and new products along with the changes of costumers' needs. But with more kinds of business development, the management difficulty will increase as well as management cost. For example, the asset securitization products released by commercial banks can promote the circulation of asset, improve the liquidity, and also increase the risk of price fluctuation. In this case, high quality administration is required in commercial banks.

Finally, noninterest income business requires higher management ability, but Chinese banks may lack this expertise. Noninterest income will increase the existing risk of commercial banks. For example, if a commercial bank lacks the experience in the investment field when developing noninterest business, it will meet high investment risk. However, at present, the noninterest products of Chinese commercial banks mostly derive from traditional business, especially when client resources are depending on the longterm building up of traditional business.

Noninterest income can lead to commercial banks' overall income increasing in the initial stage of development. But as the scale expands the marginal cost of developing noninterest income is rising and the marginal income of noninterest income is decreasing, so the rising operating costs will decrease the net income. Huang and Chen [25] find that the banks with either relatively higher or lower ratios of noninterest incomes to operating incomes perform more cost-efficiently during the examination periods. Another view [26] holds that if the proportion of commission in total income is much too high, the total profit will decrease. Noninterest income's influence on the commercial bank's performance may have constraints, and the interaction between noninterest income and interest income must be managed.

\section{Methodology}

4.1. Threshold Effect Model. To account for the potential variability in the relationship between noninterest income and performance across different commercial banks, we allow for a turning point or a "threshold" within our model. The threshold effect refers to such a state; namely, when an economic parameter reaches a specific value, it will lead to another model parameter's alteration. The specific value is called threshold value. The regression model based on this effect is called the threshold regression model. If the modelled data contains multiple individuals and multiple years, the model is a panel threshold model. We use the model of Hansen [27]. Compared with the former threshold effect regression model, the Hansen [27] threshold regression model has two advantages: firstly, this threshold regression model does not need to separate the endogenous variables and the exogenous variables, so the threshold and the estimated parameters depend only on the endogeneity; secondly, the threshold model theory offers an asymptotic distribution theory to determine the confidence interval of the parameters and to estimate the threshold's statistical significance.

Based on the hypothesis above, this paper applies the panel threshold model of Hansen [27] to study the relationship between the bank's performance and noninterest income. The specific single threshold model is as follows:

$$
\begin{array}{ll}
y_{i t}=u_{i}+x_{i t}^{\prime} \beta_{1}+e_{i t}, & q_{i t} \leq \gamma, \\
y_{i t}=u_{i}+x_{i t}^{\prime} \beta_{2}+e_{i t}, & q_{i t}>\gamma .
\end{array}
$$

Among these, $i$ denotes company and $t$ denotes time, $y_{i t}$ is the response variable, $x_{i t}$ is $p \times 1$ order explanatory variable vector, and $q_{i t}$ is the threshold variable. We use return on equity as the response variable performance measure and noninterest income as a proportion of total operating income as the main explanatory variable. The remaining explanatory variables are described in Section 4.3.

We also take the noninterest income proportion for the threshold variable. The role of the threshold variable is to 
TABLE 1: The explanation of the model variables.

\begin{tabular}{|c|c|c|c|c|}
\hline \multirow{2}{*}{$\begin{array}{l}\text { Category } \\
\text { Explained variable }\end{array}$} & \multicolumn{2}{|c|}{ Variable } & \multirow{2}{*}{$\begin{array}{l}\text { Calculation of the variable } \\
\text { Net profit/net asset }\end{array}$} & \multirow{2}{*}{$\begin{array}{l}\text { Explanation } \\
\text { The performance of profitability }\end{array}$} \\
\hline & Performance & ROE & & \\
\hline Explanatory variable & $\begin{array}{c}\text { Noninterest } \\
\text { income }\end{array}$ & NIR & $\begin{array}{l}\text { Noninterest income/total operating } \\
\text { income }\end{array}$ & $\begin{array}{l}\text { How much and how well banks } \\
\text { carry out noninterest business }\end{array}$ \\
\hline \multirow{3}{*}{ Control variable } & \multicolumn{2}{|c|}{ Bad loan ratio (BAD) } & Nonperforming loans/balance of loans & $\begin{array}{l}\text { The credit assets' security } \\
\text { condition }\end{array}$ \\
\hline & \multicolumn{2}{|c|}{ Capital adequacy ratio (CAR) } & Capital/risk-weighted asset & $\begin{array}{l}\text { How well the risk control ability } \\
\text { is }\end{array}$ \\
\hline & \multicolumn{2}{|c|}{ Cost ratio (COST) } & Operating cost/operating income & Ability of control of the cost \\
\hline
\end{tabular}

divide the samples into different groups and the turning point of the regime changing. The different regimes in the model can be denoted into two states; in one state the threshold variable is bigger than the specific threshold; in the other the threshold variable is smaller than the specific threshold.

Define dummy variable $d_{i}(\gamma)=\left(q_{i} \leq \gamma\right)$. (.) is the indicator function, which means when $q_{i} \leq \gamma,(\cdot)=1$, or $(\cdot)=0$. This way, the equations above can be expressed by a single equation:

$$
y_{i t}=u_{i}+x_{i t}^{\prime} \beta+x_{i t}^{\prime} d_{i t}(\gamma) \theta+e_{i t}, \quad e_{i t} \sim \operatorname{iid}\left(0, \sigma^{2}\right) .
$$

Thereinto, $\beta=\beta_{2} ; \theta=\beta_{1}-\beta_{2}$. Using any threshold value $\gamma$, we can get the model fit and determine the residual sum of squares (RSS). Following Hansen [27], we take the optimal threshold $\hat{\gamma}$ as the value that minimizes the RSS.

4.2. The Test of Threshold Effect Model. Test of the model includes two aspects: one is significance test of the threshold effect; the other is equivalence test between the estimator and its real value. The first null hypothesis we consider is $H_{0}: \beta_{1}=\beta_{2}$, and the test statistic is

$$
F_{1}=\frac{S_{0}-S_{1}(\widehat{\gamma})}{\widehat{\sigma}^{2}}
$$

In formula (3), $S_{0}$ is the RSS obtained under the hypothesis $H_{0}$. Under the null hypothesis $H_{0}$, the threshold value $\gamma$ cannot be identified, so the statistical distribution of $F_{1}$ is not standard. To solve this problem, we use bootstrapping to approximate the asymptotic distribution and then build the $P$ value. The second null hypothesis we consider is $H_{0}: \widehat{\gamma}=\gamma_{0}$, and the corresponding maximum likelihood ratio statistic is

$$
\operatorname{LR}_{1}(\gamma)=\frac{S(\gamma)-S(\widehat{\gamma})}{\hat{\sigma}^{2}} .
$$

The statistical distribution is also not standard. Nonetheless, Hansen [27] offers a simple formula to calculate a rejection region. When $L_{1}(\gamma) \leq c(\alpha)$, we cannot reject the null hypothesis, where $c(\alpha)=-2 \ln (1-\sqrt{1-\alpha})$ and where $\alpha$ is the significance level.

4.3. Data and Indicators. This paper analyses a dataset containing 16 listed commercial banks, covering the period of 2007 to 2013 . This includes 5 state owned commercial banks, 8 joint-equity commercial banks, and 3 municipal commercial banks. The resources of data are Almanac of China's Finance and Banking, the public annual report of each commercial bank, and the BankScope database.

There are three types of variables in this paper: commercial bank's performance (the dependent variable), the noninterest income as a proportion of total income, and other control variates (see Table 1). We use return on equity (ROE) to represent the performance of commercial banks. The reason is that, according to the DuPont formula,

$$
\begin{aligned}
\mathrm{ROE}= & \frac{\text { net profit }}{\text { net equity }} \\
= & \left(\frac{\text { net profit }}{\text { operating income }}\right) *\left(\frac{\text { operating income }}{\text { total asset }}\right) \\
& *\left(\frac{\text { total asset }}{\text { net equity }}\right) \\
= & \text { profit margin } * \text { asset turnover } * \text { leverage. }
\end{aligned}
$$

In the DuPont formula, the profit margin reflects the ability of the bank to earn profit and control costs. The asset turnover reflects the efficiency of capital operation. Therefore, it is reasonable to choose $\mathrm{ROE}$ as the indicator of commercial bank's performance.

In total the dataset includes five variables for the period of 2007 to 2013: ROE (return on equity), NIR (the noninterest income as a proportion of total income), BAD (nonperforming loan ratio), CAR (capital adequacy ratio), and COST (cost ratio).

As to the explanatory variables, we set NIR as the main explanatory variable, to reflect how much and how well those commercial banks carry out noninterest business; it also has indirect impact on the scale of noninterest rate business to the whole business. We choose nonperforming loan ratio (BAD) to reflect the security condition of credit assets. The less the ratio of nonperforming loan is, the safer the operation of banks is and the more the support noninterest rate business will get from interest rate business. CAR shows how well the commercial banks manage risk control, and COST reflects the ability of commercial bank to control costs. A lower level of the cost ratio indicates the ability to provide resources for noninterest income business. 
The estimation model under single threshold condition is as follows:

$$
\begin{aligned}
\mathrm{ROE}_{i t}= & u_{i t}+\beta_{1} \mathrm{BAD}_{i t}+\beta_{2} \mathrm{COST}_{i t}+\beta_{3} \mathrm{CAR}_{i t} \\
& +\beta_{4} \mathrm{NIR}_{i t}\left(q_{i t} \leq \gamma\right)+\beta_{5} \mathrm{NIR}_{i t}\left(q_{i t}>\gamma\right) \\
& +e_{i t} \quad e_{i t} \sim \operatorname{iid}\left(0, \sigma^{2}\right) .
\end{aligned}
$$

4.4. Descriptive Statistical Analysis. In this section we consider descriptive statistics for every variable in the dataset and also consider separately the relevant variables of state owned commercial banks, joint-equity commercial banks, and municipal commercial banks.

4.4.1. Return on Equity (ROE). The mean ROE of joint-equity commercial banks across all years $(21.26 \%)$ is higher than the mean for the other two kinds of banks and is also higher than the mean of all 16 commercial banks (19.19\%). The highest ROE is $41.12 \%$, coming from China Everbright Bank in year 2007. The state owned commercial banks and jointequity commercial banks' mean ROE are $19.08 \%$ and $17.06 \%$, respectively. The performance of city commercial banks is much worse than state owned commercial banks and jointequity commercial banks, among which the highest ROE is merely $17.35 \%$. However, the statistical standard deviation of the variables shows that municipal commercial banks are more stable than state owned commercial banks and jointequity commercial banks, although the ROE of municipal commercial banks is comparatively lower. Those joint-equity commercial banks have highest ROE but fluctuate much more than other kinds of banks.

4.4.2. Nonincome Return Proportion. The state owned commercial banks' average NIR across all years is $20.45 \%$ which is the highest among the three kinds of commercial banks. Joint-equity commercial banks' NIR (15.05\%) takes the second place, $4.66 \%$ lower than that of the overall mean. This is mostly because state owned commercial banks are predominant in scale and market share and have massive customer resources in the traditional deposits and loans business. In this case, the noninterest business can be developed much easier for state owned banks. Inevitably, the higher noninterest income is associated with higher volatility. Joint-equity commercial banks' performance is better than state owned banks, but their NIR is lower than state owned commercial banks, which indicates that the higher noninterest income rate does not necessarily lead to better performance. To some extent, this validates our earlier assumption about the relationship between noninterest income and performance.

4.4.3. Control Variates. This paper selects BAD, CAR, and COST as the control variates. It is found that, except for state owned commercial banks, both the nonperforming loan ratios of joint-equity commercial banks and municipal commercial banks are lower than the overall mean. Among these, the nonperforming loan ratio of municipal commercial bank is the lowest $(0.97 \%)$, and the standard deviation is also the lowest. As for cost control, average cost ratio for
TABLE 2: The stationary test LLC result.

\begin{tabular}{lcccc}
\hline \multirow{2}{*}{ Variable } & \multicolumn{4}{c}{ LLC test } \\
& Coefficient & $t$-value & $t$-star & $P>t$ \\
\hline ROE & -0.90519 & -19.427 & -15.51336 & $0.0000^{* * *}$ \\
NIR & -0.99370 & -18.402 & -17.63716 & $0.0000^{* * *}$ \\
BAD & -0.28727 & -11.725 & -8.16048 & $0.0000^{* * *}$ \\
CAR & -0.66458 & -14.243 & -13.49747 & $0.0000^{* * *}$ \\
COST & -0.60142 & -10.544 & -7.58969 & $0.0000^{* * *}$ \\
\hline
\end{tabular}

Notes. $* * *$ denotes significance at $1 \%$ level.

16 listed commercial banks across all years is $34.46 \%$. The cost ratios of state owned commercial banks, joint-equity commercial banks, and municipal commercial banks are $22.70 \%, 36.12 \%$, and $31.19 \%$, respectively. Among these, the cost ratio of joint-equity commercial bank is higher than the mean value. As for risk control, the capital adequacy ratio for municipal commercial banks is much higher than that for joint-equity commercial banks. The Bank of Nanjing has the largest CAR in any year: $30.67 \%$ in 2007 . This shows that municipal commercial banks are relatively conservative on risk management. On the one hand it is because their scales are relatively small, and the deposits and loans business is limited; on the other hand, according to their relatively lower noninterest income, the expansion of commission and fee business is also limited. Meanwhile, there municipal commercial banks also meet gaps with state owned banks and joint-equity commercial banks in investment management.

\section{Empirical Results and Analysis}

5.1. Variable Stationary Test. We usually have to make sure that every variable is stationary when using the panel threshold regression model. So we should test the stationarity of the variable, which is known as a panel unit root test, using LLC as the test method. The test results are shown in Table 2. The null hypothesis of the LLC is $H_{0}$ : there exist unit roots. According to the $P$ value of variable ROE, NIR, BAD, and CAR, we make the conclusion that the null hypothesis should be rejected, and there are no unit roots.

5.2. Endogeneity Test. An explanatory variable's endogeneity could lead to the estimation bias. To avoid any possible endogenous variable problems, we use the Hausman endogenous test method (see Table 3 ) to test the explanatory variables.

Fe is the coefficient of the fixed effect. Re is the coefficient of random effect. According to the null hypothesis, there is no systematic difference between the fixed effect and random effect coefficients. Table 3 gives an overall $P$ value of 0.4473 . We accept the null hypothesis that no endogeneity exists in the explanatory variables.

5.3. Threshold Value Test. When using panel data to estimate threshold model, we should first define the quantity of the thresholds, which is also the quantity of structural change points, to determine the specific form of the model. We consider that, as the noninterest income rate changes, there 
TABLE 3: Endogeneity test result.

\begin{tabular}{|c|c|c|c|c|}
\hline Variable & $\begin{array}{l}\text { (b) } \\
\text { fe }\end{array}$ & $\begin{array}{l}(B) \\
\text { re }\end{array}$ & $\begin{array}{c}(b-B) \\
\text { Difference }\end{array}$ & $\begin{array}{c}\operatorname{sqrt}\left(\operatorname{diag}\left(V_{-} b-V_{-} B\right)\right) \\
\mathrm{SE}\end{array}$ \\
\hline BAD & -0.8938821 & -0.8729335 & -0.0209486 & 0.0827101 \\
\hline COsT & -0.1579967 & -0.194983 & 0.0369863 & 0.0755033 \\
\hline CAR & -0.4142893 & -0.5194039 & 0.1051146 & 0.0974391 \\
\hline NIR & -0.1971864 & -0.1767028 & -0.0204837 & 0.0602813 \\
\hline
\end{tabular}

$b=$ consistent under $\mathrm{H} 0$ and $H a$, obtained from xtreg.

$B=$ inconsistent under $\mathrm{Ha}$ and efficient under $\mathrm{H} 0$, obtained from xtreg.

Test. H0: difference in coefficients not systematic.

$\operatorname{chi} 2(4)=(b-B)\left[\left(V \_b-V \_B\right)^{\wedge}(-1)\right](b-B)=3.71$.

Prob $>$ chi $2=0.4473$

TABLE 4: Threshold test results.

\begin{tabular}{lccccc}
\hline Model & \multirow{2}{*}{ F-statistic } & P value & The frequency of bootstrap & \multicolumn{3}{c}{ Critical value } & \multicolumn{2}{c}{ 1\% } & $5 \%$ \\
\hline Single threshold & $24.5959^{* * *}$ & 0.0000 & 1000 & 6.86629 & 4.16177 \\
Double threshold & $11.1334^{* * *}$ & 0.0020 & 1000 & 6.54412 & 3.62866 \\
Triple threshold & $5.9955^{* *}$ & 0.0180 & 1000 & 5.92804 & 3.51374 \\
\hline
\end{tabular}

Note. $* * *$ and $* *$ separately denote the significance at $1 \%$ and $5 \%$ level.

may be up to three structural change points (thresholds) between noninterest income and the performance. We estimate the models, and test for existence of change points using the $F$-statistic and the associated $P$ value derived from 1000 bootstrap replications. These are shown in Table 4 .

From Table 4, the F-statistics for single threshold, double threshold, and triple threshold are 24.5959, 11.1334, and 5.9955, respectively. Single threshold and double threshold models are both significant at $1 \%$ level, and the bootstrap $P$ values are 0.0000 and 0.0020 ; the triple threshold is only significant at $5 \%$ level. We use a $1 \%$ level and therefore employ a double threshold model.

The estimated thresholds for the double threshold model are 0.0998 and 0.1662 . This means that the effect of noninterest income on performance of commercial banks will change structurally when noninterest income rate is lower than $9.98 \%$, between $9.98 \%$ and $16.62 \%$, and higher than $16.62 \%$.

For comparison purposes we fit both the no threshold model and the double threshold model. The parameter estimates are shown in Tables 5 and 6. From Table 5 under the no threshold model, at 5\% significance level, the significant negative coefficients are merely nonperforming loan ratio (BAD) and CAR. The coefficients of COST and NIT are also negative but not significant at the $5 \%$ level, although the coefficient of NIT is significant at the $10 \%$ level.

Intuitively, the higher the NIT is, the better the performance of commercial bank will be. However, the no threshold model shows that NIT and the performance are negatively related. The reason can be summarized as follows: the operating expenses deriving from noninterest income business are much higher than that of the interest income business. The interest income derives from loan business. From the current situation, management and cost control level for loan business cannot be further improved. So the marginal cost of interest income is quite low and barely grows after the interest income increases. However the noninterest income has been newly developed in the last 10 years. Compared to the loan business management and cost control level, these emerging businesses still have a long way to go. Moreover, banks investment income and exchange earning are influenced by secondary market and foreign exchange market price fluctuation, so negative profits are common, which means that deficits often happen in these two operations even though human and material resources have been allocated. The composition of the above two factors causes the higher expenses of acquiring noninterest income than interest income. Therefore, NIR can be negatively correlated with bank performance.

On the other hand, the result of the no threshold model shows that the coefficient of noninterest is only significant at $10 \%$ level. This may be caused by the strict supervision of China Banking Regulatory Commission (CBRC). Some innovation applications of noninterest operation have been refused by CBRC with the consideration of unfavorable impacts on noninterest business. The constraints of the policy make the effect of noninterest operation on bank's performance more limited.

From Table 6, when we add the two threshold values, noninterest income ratio becomes significant. And the coefficients are significantly different in different threshold interval. When noninterest income ratio is less than 0.0998 , the coefficient estimated by threshold model is -1.8229 , which means the return on equity (ROE) is negatively correlated with noninterest income (NIR); when the noninterest income ratio is between 0.998 and 0.1662 , the coefficient of noninterest income grows to -0.7525 , but the correlation between ROE and NIR is still negative. When noninterest income 
TABLE 5: Estimated results of no threshold model.

\begin{tabular}{lcccc}
\hline Explanatory variable & Coef & Std & $t$ & \multicolumn{1}{c}{ Prob } \\
\hline BAD & -0.8939 & 0.2043 & -4.3758 & $0.0000^{* * *}$ \\
COST & -0.1580 & 0.1302 & -1.2132 & 0.2281 \\
CAR & -0.4143 & 0.1856 & -2.2321 & $0.0280^{* *}$ \\
NIR & -0.1972 & 0.1013 & -1.9458 & $0.0547^{*}$ \\
\hline
\end{tabular}

Note. $* * *, * *$, and $*$ separately denote the significance at $1 \%, 5 \%$, and $10 \%$ level.

TABLE 6: Estimates of double threshold model.

\begin{tabular}{lcccc}
\hline Explanatory variable & Coef & Std & $t$ & Prob \\
\hline BAD & -0.8595 & 0.1771 & -4.8516 & $0.0000^{* * *}$ \\
COST & -0.0539 & 0.1121 & -0.4805 & 0.6321 \\
CAR & -0.4234 & 0.1628 & -2.6010 & $0.0109^{* *}$ \\
NIR $(<0.0998)$ & -1.8229 & 0.2784 & -6.5482 & $0.0000^{* * *}$ \\
NIR $(0.0998 \sim 0.1662)$ & -0.7527 & 0.1562 & -4.8202 & $0.0000^{* * *}$ \\
NIR $(>0.1662)$ & -0.5046 & 0.1042 & -4.8443 & $0.0000^{* * *}$ \\
\hline
\end{tabular}

Note. $* * *$ and $* *$ separately denote the significance at $1 \%$ and $5 \%$ level.

ratio surpasses the second threshold 0.1662 , the coefficient of noninterest income ratio grows further to 0.5046 . As the noninterest ratio grows up, the negative effect of noninterest income reduces, which means the performance can be improved.

The reason why the coefficient of noninterest income ratio grows after noninterest income ratio and generates threshold effects can be summarized as follows.

Firstly, the average cost of noninterest business reduces after the noninterest business grows. At the initial period of commencing noninterest business, the investment is relatively high. The investment includes new manpower, the expense of product research, and marketing cost. However, when noninterest business has been finely developed, the bank only needs to maintain the clients and the system, so the operation cost reduces. Overall, the preparation of noninterest business is a massive investment, but when the business line is highly developed, the variable cost just slightly grows with volume growing, which means the fixed cost is high but the marginal cost is quite low. The reduction of average cost of noninterest business will improve the performance of commercial banks.

Secondly, the increase of noninterest income ratio will enhance the total asset turnover of commercial banks. Total asset turnover is equal to net operation income within a certain period divided by total average assets of that period. Compared with loan operation, the main character of noninterest business is that noninterest business is not linked with assets, while the income from loans is linked with assets of the bank. In this way, on the development of banks, the rising rate of the interest income is remarkably similar to the average rising rate of total assets. So, when the noninterest income ratio rises, the numerator of total asset turnover grows faster than denominator, so the total asset turnover can be improved. From DuPont formula, ROE is a product of 3 different parts: total asset turnover, return on sales, and leverage ratio. So, when the rise of the noninterest income ratio makes the total asset turnover improve, the performance can be also improved.

\section{Conclusion}

Generally noninterest income of Chinese commercial banks is influenced by regulations from the central bank, techniques, and innovation. Faced with intensified competition induced by increasingly open market policies of China, Chinese commercial banks strive to compete in noninterest income activities. This paper analyses whether the noninterest income activities help enhance the banks' performance. Starting with the hypothesis of a threshold effect from noninterest income business on commercial banks' performance, this paper builds empirical model of the threshold effect and evaluates the threshold value. This indicates the following: (1) noninterest rate is negatively correlated with the performance of commercial bank; the higher the noninterest rate is, the lower the performance of commercial bank will be; (2) two thresholds are 0.0998 and 0.1662 , which shows that the influence of noninterest income business on commercial banks performance has structural change in three intervals: lower than $9.98 \%$, between $9.98 \%$ and $16.62 \%$, and higher than $16.62 \%$.

When noninterest rate is higher than the two threshold values, the negative relationship will weaken, so that when noninterest income reaches that point it will improve the relative performance. Our research also shows the coefficient between noninterest income rate and performance inclines to zero as the noninterest income rises. This suggests that when noninterest income reaches higher threshold, the negative relationship will gradually recede, and the coefficient may even become positive, which means the increase of noninterest income may improve the performance. So the policy implication of our research is to provide more resources to noninterest income activities and put more emphasis on the 
quality supervision and efficiency supervision on noninterest income activities.

\section{Competing Interests}

The authors declare that they have no competing interests.

\section{References}

[1] A. M. Santomero and D. L. Eckles, "The determinants of success in the new financial services environment: now that firms can do everything, what should they do and why should regulators care?" Federal Reserve Bank of New York, Economic Policy Review, vol. 6, no. 4, pp. 11-23, 2000.

[2] R. Deyoung and K. P. Roland, "Product mix and earnings volatility at commercial banks: evidence from a degree of total leverage model," Journal of Financial Intermediation, vol. 10, no. 1, pp. 54-84, 2001.

[3] M. Ariff and F. F. Cheng, "Do accounting disclosures of fee income affect commercial bank share prices?" CARF Working Paper 7, 2008.

[4] J. Goddard, D. McKillop, and J. O. S. Wilson, "The diversification and financial performance of US credit unions," Journal of Banking \& Finance, vol. 32, no. 9, pp. 1836-1849, 2008.

[5] B. S. Damankah, O. Anku-Tsede, and A. Amankwaa, International Journal of Academic Research in Accounting, vol. 4, no. 4, pp. 263-271, 2014.

[6] R. Engle, F. Moshirian, S. Sahgal, and B. Zhang, "Banks non-interest income and global financial stability," Research Working Paper Series 3-56 Working Paper No. 015/2014, CIFR, 2014.

[7] K. Jaffar, K. Mabwe, and R. Webb, "Changing bank income structure: evidence from large UK banks?" Asian Journal of Finance \& Accounting, vol. 6, no. 2, pp. 195-215, 2014.

[8] S. R. Trivedi, "Banking innovations and new income streams: impact on banks' performance," Vikalpa, vol. 40, no. 1, pp. 2841, 2015.

[9] D. B. Senyo, A.-T. Olivia, and A. Musah, "Income diversification and financial stability of banks in Ghana," International Journal of Business and Social Science, vol. 6, no. 6, 2015.

[10] T. C. Nguyen, D. V. Vo, and V. C. Nguyen, "Risk and income diversification in the Vietnamese banking system," Journal of Applied Finance \& Banking, vol. 5, no. 1, pp. 93-109, 2015.

[11] R. De Young and T. Rice, "How do banks make money? The fallacies of fee income," Federal Reserve Bank of Chicago Economic Perspectives, vol. 40, pp. 34-51, 2004.

[12] P. Eisemann, "Diversification and the congeneric bank holding company," Journal of Bank Research, vol. 7, no. 1, pp. 68-77, 1976.

[13] R. Busch and T. Kick, Income Diversification in the German Banking Industry, Discussion Paper 9, Bundes Bank, 2009.

[14] H. Aggeler and R. Feldman, "Record bank profitability: how, who and what does it mean?" Federal Reserve Bank of Minneapolis, no. 10, 1998.

[15] H. Sheng and B. Wang, "Impact of non-interest income on performance of Chinese listed commercial banks," Finance Forum, no. 6, pp. 8-11, 2008.

[16] S. Sanya and S. Wolfe, "Can banks in emerging economies benefit from revenue diversification?" Journal of Financial Services Research, vol. 40, no. 1, pp. 79-101, 2011.
[17] A. Saunders, M. Schmid, and I. Walter, Non-Interest Income and Bank Performance: Is Banks' Increased Reliance on NonInterest Income Bad?, 2014, http://ssrn.com/abstract=2504675.

[18] K. J. Stiroh and A. Rumble, "The dark side of diversification: the case of US financial holding companies," Journal of Banking and Finance, vol. 30, no. 8, pp. 2131-2161, 2006.

[19] F. Aslam, B. Mehmood, and S. Ali, "Diversification in banking: is non interest income the answer for Pakistan's case?" Science International (Lahore), vol. 27, no. 3, pp. 2791-2794, 2015.

[20] A. Saunders, M. Schmid, and I. Walter, Non-Interest Income and Bank Performance: Does Ring-Fencing Reduce Bank Risk? 2016, http://ssrn.com/abstract=2504675.

[21] R. Smith, C. Staikoura, and G. Wood, "Non-interest income and total income stability," Working Paper 198, Bank of England, 2003, http://www.bankofengland.co.uk/wp/index.html.

[22] S. Mercieca, K. Schaeck, and S. Wolfe, "Small European banks: benefits from diversification?" Journal of Banking and Finance, vol. 31, no. 7, pp. 1975-1998, 2007.

[23] R. K. Mndeme, "Impact of non interest income on banking. Performance in Tanzania," International Journal of Economics, Commerce and Management, vol. 3, no. 5, pp. 75-92, 2015.

[24] C. Calmès and Y. Liu, "Financial structure change and banking income: a Canada-U.S. comparison,” Journal of International Financial Markets, Institutions and Money, vol. 19, no. 1, pp. 128139, 2009.

[25] L.-W. Huang and Y.-K. Chen, "Does bank performance benefit from non-traditional activities? A case of non-interest incomes in Taiwan Commercial Banks," Asian Journal of Management and Humanity Sciences, vol. 1, no. 3, pp. 359-378, 2006.

[26] L. Lepetit, E. Nys, P. Rous, and A. Tarazi, "The expansion of services in European banking: implications for loan pricing and interest margins," Journal of Banking and Finance, vol. 32, no. 11, pp. 2325-2335, 2008.

[27] B. E. Hansen, "Threshold effects in non-dynamic panels: estimation, testing, and inference," Journal of Econometrics, vol. 93, no. 2, pp. 345-368, 1999. 

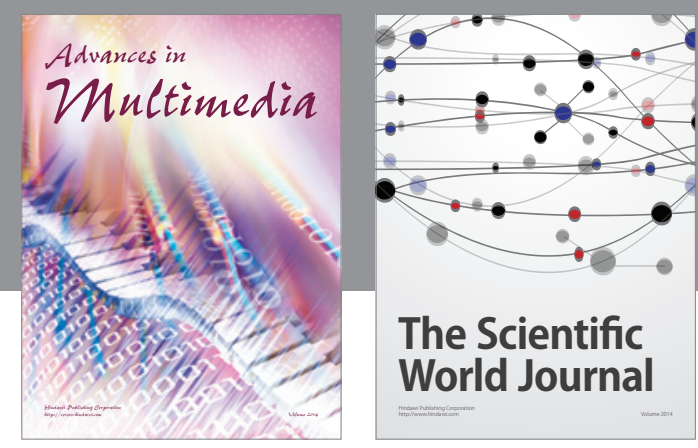

The Scientific World Journal
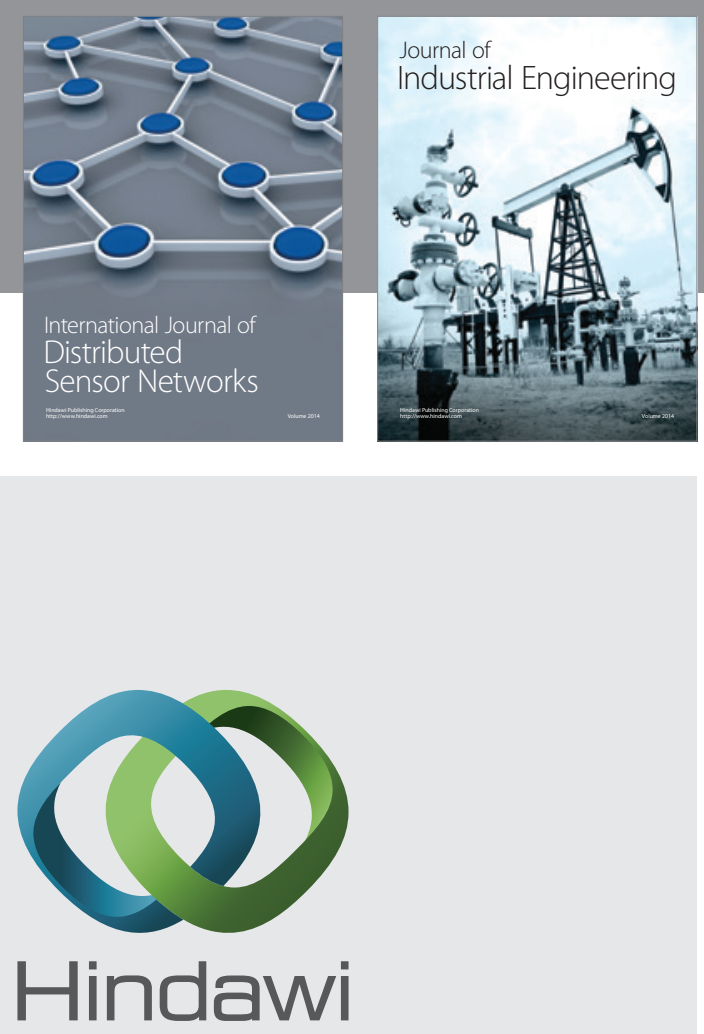

Submit your manuscripts at

https://www.hindawi.com

\section{Computer Networks} and Communications
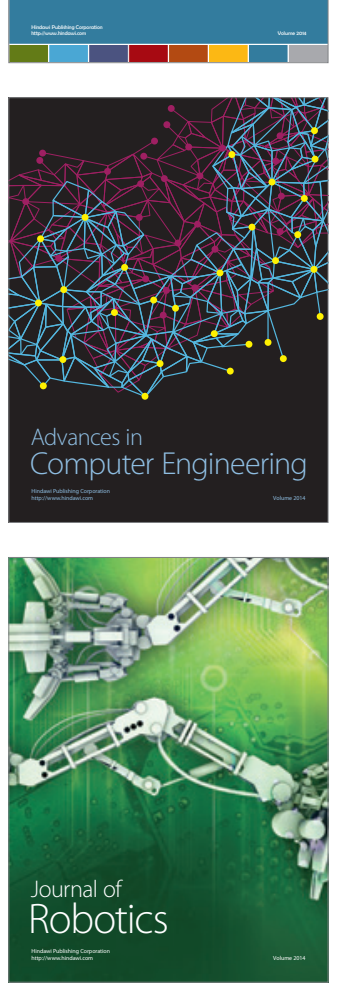
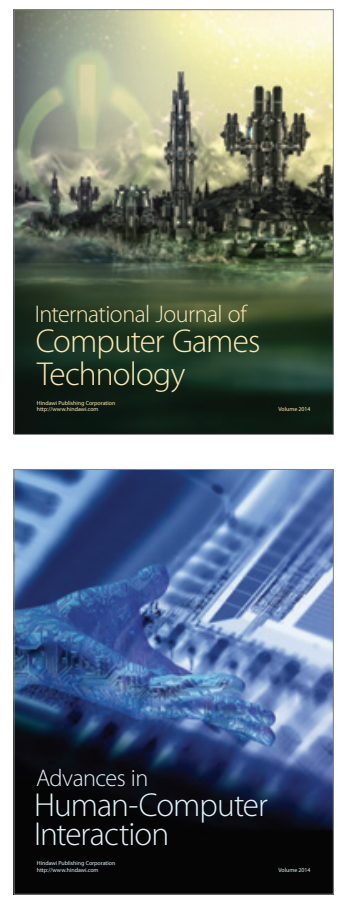
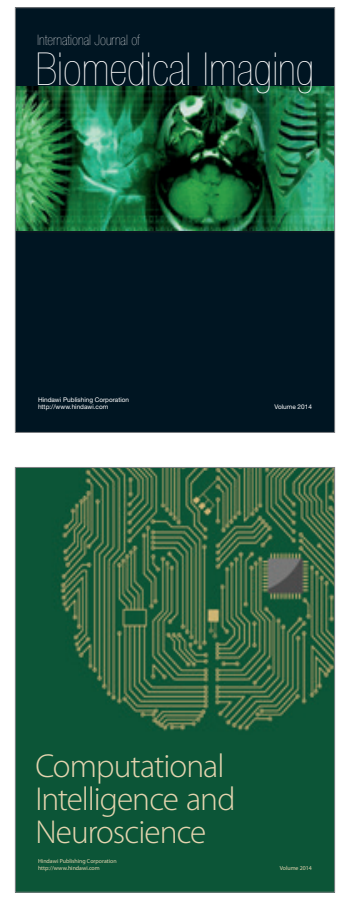
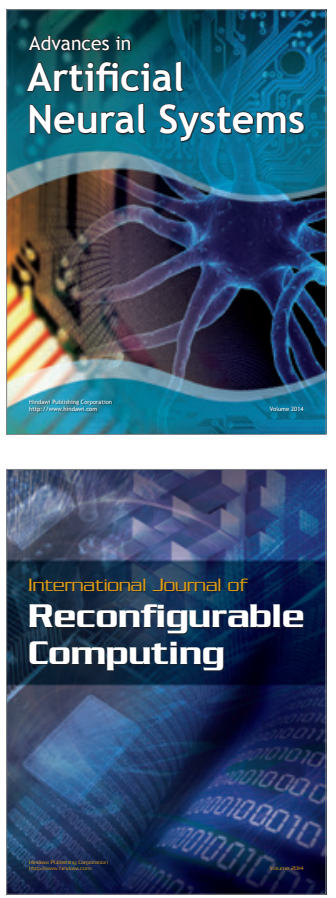
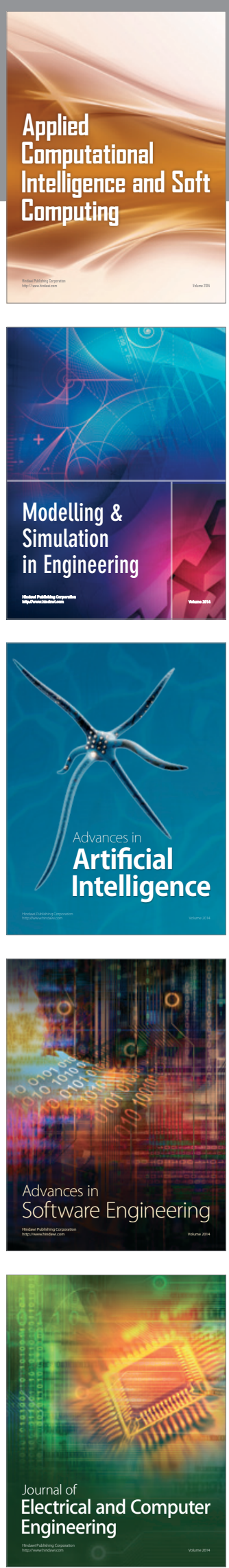